\title{
PENERAPAN PANCASILA PERSPEKTIF ISLAM
}

\author{
Oleh : Husnul Khotimah S, S.Ag, M.Si., ${ }^{1}$
}

\begin{abstract}
Regarding Pancasila Values in the Islamic View, the first and second precepts constitute the Metaphysical Fundation, the third and fourth precepts constitute the Instrumental Fundation, and the fifth precepts constitute justice. Therefore we must do: mahasabah (evaluation), murakabah (guarding / supervising), and muhawalah (getting around) Islam as a religion that upholds egalitarianism, which is an open concept of solidarity and social dependence (ta ‘wun). Islam recognizes the right of all humans to live properly in terms of health, clothing, food, housing and social efforts that are needed regardless of differences in background. Islam also emphasizes the right of everyone to social security at the time of unemployment, illness, disability, widow / widower, elderly or disadvantaged. This standard of living is only possible in a healthy social order, where individuals with individuals, individuals with groups, and groups with groups maintain strong social relations. This has become the spirit of Islam in being responsible and sacrificing one another in order to create a community that shares, helps and helps each other. The piety of the faithful as slaves to Allah ('abd Allah) boils down to a direct impact on piety in social-horizontal relations. These two aspects characterize the balance of Islamic teachings. Therefore, what should be our thoughts together is that the values of Pancasila are substantially not in conflict with or even in accordance with Islam.
\end{abstract}

Keyword : pancasila, Islam, Nilai

\section{Pendahuluan}

Pancasila telah menjadi kesepakan bangsa Indonesia dengan segala pertimbangan, baik seperti letak geografis, kondisi demografi, serta kekayaan budaya nusantara. Hal ini disebut sebagai sesuatu yang final ataupun dengan sebutan "The Great Oughts". Pancasila diyakini sebagai dasar yang mampu mempersatukan bangsa dari kayanya suku ras dan budaya yang dimilikinya sehingga Pancasila diyakini bahwa nilai-nilai mampu mewujudkan nilai-nilai toleransi anatara ummat beragama. Tanpa pemersatu maka tidak ada kekuatan bangsa sebagaimana pendapat dari politisi Amerika Serikat Jhon Gardner bahwa "tidak ada bangsa yang dapat mencapai kebesaran ataupun keagungan jika tidak memiliki sesuatu yang dipercaya dan yang dipercayainya itu memiliki dimensi moral untuk mempertahankan peradaban warga negaranya".

Pancasila merupakan falsafah bangsa dan dasar Negara Indonesia, yang seharusnya menjadi kerangka dasar norma-norma bernegara dan bermasyarakat yang bermartabat.

Kondisi bangsa saat ini sungguh sangat memprihatinkan, dirasakan bahwa kondisi bangsa saat ini mencerminkan belum diimplementasikan dan diperaktekannya dalam kehidupan sehari-hari secara langsung. Segala perpecahan dan konflik yang terjadi sangat jauh dan tidak mencerminkan jati diri bangsa yang sesungguhnya. Perpolitikan yang terjadi marak dengan isu-isu sara, budaya, agama, etnis, dan 
golongan, hal ini tentunya sangat berbahaya bagi disintegrasi bagi seluruh wilayah kesatuan Indonesia.

Perpecahan terjadi di semua sektor kehidupan berbangsa dan bernegara akibat dari kesalahan implementasi etika politik yang dilakukan di tengah masyarakat Indonesia. Konflik sengaja diciptakan ditengah masyarakat guna mencapai kepentingan pribadi dan golongan semata, nilai-nilai luhur dan peradaban mulia yang ada tergores oleh setitik tinta hitam demi sebuah transaksi politik sesat dan sesaat. Hal ini tentu sangat disayangkan bagi keberlangsungan kehidupan bermasyarakat Indonesia, yang menyisakan runtuhnya etika politik, nilai-nilai luhur budaya dan peradaban bangsa yang mulia yang terkenal ramah, santun, agamis, berprilaku baik, tulus dan budaya gotongroyong dalam setiap kegiatan social ditengah kehidupan masyarakat.

Hal ini tentunya sangat merugikan kedaulatan, ketahanan, dan kemajemukan budaya bangsa Indonesia. Secara tidak disadari oleh semua lapisan masyarakat bahwa gap terjadi akibat kejahatan politik yang menggunakan cara-cara kotor, demi sebuah ambisi jabatan, kehormatan dan dunia semata. Satu dengan yang lain nya di adu dan di rusak persaudaraan, pertemanan, dan jalinan kesatuan persatuan umat di lapangan.

Maka sangatlah penting bahwa penerapan nilai-nilai pancasila di tengah masayarat disinergikan kembali dengan ajaran-ajaran Agama di sekolah dan institusi pendidikan lanjut kepada anak didik dan generasi bangsa, guna menopang keutuhan NKRI, kemandirian, kedaulatan, dan peradaban budaya dan tanah air Indonesia. Karena pada hakekatnya tidak ada satu agamapun mengajarkan tentang keburukan sikap dan tingkah laku kepada seluruh manusia.

Oleh karena itu sudah sepatutnya, Indonesia yang mayoritas muslim terbesar di dunia, menjadi cermin bagi Negara-negara lain dalam melakukan aktivitas di segala bidang yang senantiasa menjungjung tinggi nilai-nilai luhur, budi pekerti yang baik yang tercermin dalam ajaran agama Islam yang dituntun dalam Al-Qur'an. Nilai luhur yang terkandung dalam kitab suci Al-Qur'an tersebut merupakan bukti bahwa Islam merupakan agama yang mengajarkan kelembutan sikap, akhlak karimah, budi luhur, tutur kata dan bahasa, cara berkehidupan di masyarakat, semua sector kehidupan di kupas dalam Al-qur'an, baik ekonomi, politik, tata Negara, kepribadian, kepemimpinan, dan lain sebagainya. Hal ini sudah menjadi bukti tauladan bagi seluruh umat dunia dimana apa yang tertuang dalam Al-Qur'an dipraktekkan dalam kehidupan sehari-hari oleh Nabi Muhammad SAW. Sehingga patutlah bahwa Rasulullah menjadi contoh dan menjadi hal yang tidak terpisahkan antara Al-Qur'an dan kepribadian Rasulullah. Rasulullah dianggap melekat sebagai Al-Qur'an berjalan, karena seluruh karakter kepribadian Rasulullah sudah tertuang dalam Al-Qur'an itu sendiri.

Akhir-akhir ini suara-suara untuk menegakkan syariat Islam secara keseluruhan kembali mencuat. Seruan ini disertai dengan usaha-usaha untuk menyebarkan ideologi kekhilafahan Islam sebagai dasar negara menggantikan Pancasila dan UUD 45. Bagi mereka, Pancasila dengan lambang burung Garudanya merupakan salah satu jenis kemusyrikan dan bahkan layak disebut thagut. Jelas pemikiran seperti ini merupakan hasil pembacaan yang nominalis, pembacaan yang fokus kepada nama, bukan semangat yang dikandung nama tersebut.

Dalam Pancasila, tidak ada sila-sila yang dapat menjerumuskan ke dalam sistem kesyirikan atau ke-thagut-an. Coba perhatikan baik-baik lima sila dalam 
Pancasila. Semuanya merupakan pesan-pesan yang bersesuaian dengan nilai universal Islam. Bagi kita yang akrab dengan pemikiran al-Ghazali, as-Syatibi, Izzudin bin Abd Salam, al-Qaffal, Ibnu Asyur, Allal al-Fasi, ar-Raysuni dan lain-lain, ketika membandingkan semangat nilai yang terkandung dalam Pancasila dan UUD 45 dengan nilai-nilai universal Islam lewat kacamata pemikiran mereka, niscaya kita akan sampai kepada kesimpulan bahwa kedua dasar negara ini sesuai dengan maqasid al-syariah.

\section{PENERAPAN PANCASILA DALAM KERANGKA NILAI-NILAI ISLAM}

Sebagaimana yang telah diketahui bersama, bahwa alasan Pancasila diberlakukan sebagai ideologi bangsa yaitu demi persatuan semua pihak, persatuan seluruh penduduk Indonesia. Dengan tidak melupakan kaum Islamis di masa itu, Pancasila memiliki esensi penting mengenai keagamaan. Namun, hal yang juga penting untuk diketahui oleh umat Islam, menurut Munawir Syadzali, bahwa dipilihnya Pancasila dan bukan Islam sebagai Ideologi negara tidak semata-mata dimaksudkan demi memelihara kedamaian dan kerukunan, melainkan juga karena AlQur'an dan Hadits tidak secara eksplisit mewajibkan orang Islam mendirikan negara Islam. ${ }^{2}$ Sehingga Pancasila bukan merupakan ide sekuler, melainkan menyatukan antara kehidupan agama dengan kehidupan sosial bermasyarakat. Bahkan di setiap sila dalam Pancasila memiliki arti tersendiri yang sejalan dengan nilai-nilai Islam, atau Pancasila merupakan hasil manifestasi dari nilai-nilai Islam itu sendiri. Berikut penjelasan mengenai kesamaan antara Pancasila dengan nilai-nilai Islam yang terkandung dalam Al-Qur'an:

\section{Ke-Tuhanan Yang Maha Esa : Ketauhidan \& Hablum Min Allah (Sila Pertama)}

Sila pertama yang berbunyi "Ketuhanan Yang Maha Esa" merupakan sendi tauhid di dalam Islam. Sudah menjadi fitrah manusia secara naluriah memiliki potensi bertuhan dalam bentuk pikir dan zikir dalam rangka mengemban misi sebagai khalifah fil-ardhi, serta keyakinan yang terkadang tidak sanggup untuk dikatakan, yaitu kekuatan yang maha segala, sebuah kekuatan di atas kebendaan fana. ${ }^{3}$ Hakikat tauhid di dalam Al-Qur'an sangat jelas termaktub dalam surat Al-Ikhlash ayat 1-4, yang berbunyi:

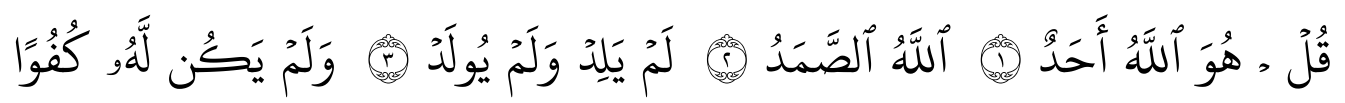

"Katakanlah: "Dia-lah Allah, yang Maha Esa. Allah adalah Tuhan yang kepada-Nya segala sesuatu bergantung. Dia tiada beranak dan tidak pula diperanakkan, dan tidak ada seorangpun yang setara dengan Dia."

Surat ini meliputi dasar yang paling penting dari risalah Nabi saw. yaitu mentauhidkan Allah dan menyucikan-Nya. Keesaan Allah meliputi tiga hal: Dia Maha Esa pada zat-Nya, Maha Esa pada sifat-Nya dan Maha Esa pada afal-Nya. Maha Esa pada zat-Nya berarti zat- Nya tidak tersusun dari beberapa zat atau bagian. Maha Esa pada sifat-Nya berarti tidak ada satu sifat makhlukpun yang menyamai-Nya dan Maha Esa pada af'al-Nya berarti hanya Dialah yang membuat semua perbuatan sesuai dengan firman-Nya. Sangat jelas sekali bahwa dalam Islam, umat manusia harus mengakui adanya satu Tuhan yang diyakini dan disembah. Begitu pula dengan Pancasila, yang menyatakan adanya ketuhanan yang juga satu, meskipun berbeda agama. Allah tidak pernah memaksa hamba- Nya untuk menyembah kepada-Nya, 
karena kesadaran akan bertuhan merupakan fitrah, seperti yang telah dijelaskan di atas. Selain itu, salah satu bentuk toleransi dalam Islam mengenai bertuhan yaitu, "Lakum dinukum waliadiin" yang tidak memaksa orang lain untuk masuk dalam Islam secara paksa. Dalam sila ini, terdapat unsur-unsur yang melibatkan hubungan antara manusia dengan Tuhan, yang dalam Islam disebut hablu min Allah. Dalam berhadapan dengan Allah, seorang muslim menempati kedudukan sebagai hamba, sehingga tampaklah kepatuhan dan kecintaan dalam pengabdian. Dengan demikian terdapat keterikatan yang yang kemudian melahirkan komitmen (dimensi akidah). Komitmen ini pun tampak dari pernyataan setiap muslim ketika menyatakan ikrar do'a iftitah "inna shaalatii wa nusuki wa mahyaya wa mamaatii lillaahi...". Jika setiap muslim menghayati makna ikrar tersebut, maka sesungguhnya kesaksian tersebut harus diupayakan wujud aktualnya dalam kehidupan dengan sungguhsungguh. Berkaitan dengan tauhid, sebelumnya kita mempelajari dahulu mengenai iman, yang tersusun dalam beberapa rangka atau cabang, yaitu: ${ }^{4}$

1) Aqidah, membahas asas beragama yang berupa keimanan atau keyakinan tentang jagat raya dan kekuatan supranatural yang ada. Pembahasan akidah sangat erat kaitannya dengan tauhid.

2) Syari'ah, terbagi atas ibadah khusus (mahdhah/ritual) dan mu'amalah (ibadah sosial. Sedangkan ibadah sosial mencakup beberapa bidang, antara lain bidang keluarga (al-ilah), kemasyarakatan (as-siyasah), ekonomi (al-iqtishadiyah), pendidikan (at-tarbiyah), kesenian dan kejasmanian.

3) Akhlaq, membahas mengenai tata krama dalam kehidupan pribadi, sosial, berbangsa dan bernegara. Lalu, tauhid yang merupakan inti aqidah Islam terbagi atas dua bagian, yaitu: a. Ushuluddien, yang juga disebut ilmu ma'rifat, ilmu kalam atau teologi Islam.

b. Monoteisme, yaitu mempercayai satu Tuhan, seperti yang telah dijelaskan dalam surat Al-Ikhlas ayat 1-4

Pemahaman akan Tuhan adalah sesuatu yang sentral bagi seorang muslim. Islam, yang membawa doktrin tauhid, dituntut untuk menjelaskan bagaimana maksud ajaran tauhid secara rasio. Pembahasan tentang ini dikenal dengan ilmu kalam. Salah satu aliran terpenting dalam ilmu kalam adalah Mazhab Asy'ariyah. Mazhab ini menjelaskan secara logis (aqli; hal yang ketidakadaannya dianggap mustahil oleh akal) bahwa harus ada Tuhan Yang Esa. Dr. Abu al-Ala Afifi menerangkan bahwa pembahasan tentang Tuhan pada akhirnya mengantarkan ulama saat itu kepada pemahaman bahwa Tuhan adalah wujud hakiki dan yang lain adalah wujud artifisial karena yang lain itu tidak harus ada (mumkin al-wujud). Konsekuensinya: alam adalah ketiadaan karena yang hakiki hanyalah Allah SWT. Pemahaman ini secara teoretis pada akhirnya dielaborasi secara ilmiah oleh seorang ahli kalam, ahli tasawuf secara 'ilmi dan 'amali, serta ahli fikih (sebuah kombinasi keahlian yang hampir tidak ada saat itu) yakni al-Ghazali dalam karyanya, Ihya' Ulum al-Din. Beliau mengatakan bahwa tauhid memiliki empat tingkatan. Tingkatan pertama adalah mengakui keesaan Tuhan dengan lisan tapi tidak dengan hati. Kedua, meyakini keesaan Tuhan dengan hati seperti halnya mayoritas orang awam. Ketiga, menyaksikan keesaan Tuhan dengan cara menyingkapnya melalui cahaya kebenaran. Keempat, tidak melihat eksistensi kecuali keesaan. Beliau berkata ${ }^{5}$ :

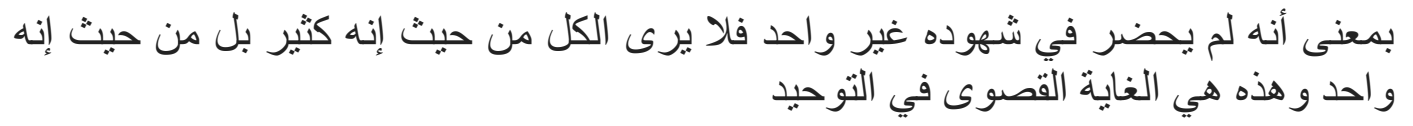


"Maksudnya adalah yang hadir dalam penglihatannya hanya ketunggalan. Oleh karena itu ia tidak memandang segala sesuatu sebagai hal yang bermacammacam, akan tetapi sebagai suatu hal yang tunggal. Keyakinan ini adalah puncak tertinggi dalam tauhid."

Menurut beliau derajat ini yang dinamakan dengan fana'. Menurut beliau orang yang sampai pada derajat ini akan melihat Yang Maha Benar (al-Haqq) dalam segala sesuatu. Syekh Ihsan Jampes dalam Siraj al-Thalibin menganalogikan tingkatan ini dengan orang yang silau karena cahaya matahari memenuhi seluruh ufuk. Meskipun orang ini hanya melihat cahaya matahari, namun sah-sah saja jika dia berkata bahwa dia sedang melihat matahari. Karena cahaya yang memancar itu pada hakikatnya adalah matahari. Begitu juga eksistensi (al-wujud), meskipun itu hanya penampakan Allah SWT (anwar al-qudrat al-azaliyah) namun sah-sah saja jika seorang sufi mengatakan bahwa ia sedang menyaksikan-Nya.

Ali Issya Othman mengawali bukunya tentang manusia menurut Al-Ghazali yang disadur ulang dalam buku NU Pancasila oleh Einar Martahan Sitompul mengungkapkan bahwa " dorongan hati (fitrah) itulah yang menyebabkan manusia menyerahkan diri (Islam) kepada Allah, (2010: 174). Kepasrahan diri total pada yang Maha Mutlak, atau tunduk dan taat pada Yang Maha menundukan, dengan kepasrahan atau keterpaksaan, dengan ketulusan atau ketidaktulusan, yang kasemuanya telah digariskan dalam garis gerak takdir oleh Sang Pemberi Takdir di awal pra-eksistensi kejadian manusia.

Fitrah dalan Islam yang pada hakekatnya menyerahkan diri (self-commitment) sebagai respon terhadap gerak hati yang tertanam didalam fitrah manusia, merupakan suatu kedamaian bathin yang tidak dapat diperoleh tanpa menemukan Allah dan menyembah kepada-Nya, pada posisi inilah maka, konsepsi fitrah itu dikalah seluruh gerak hidup manusia baik dengan kerelaan maupun keterpaksaan poros dan tujuan sentarnya adalah Tuhan itu sendiri, sekalipun dalam gerak hidup manusia mengalami ketercerabutan atau distorsi ke-Tuhanannya, tidak bisa "me-munafik-kan" apalagi mengingkari untuk meng-kosong-kan, dan menihilkan eksistensi Tuhan dalam dirinya, merasa Tuhan senantiasa hadir atau keyakinan ke-Tuhannnya tidak akan hilang, tetap melekat dalam bathin inilah dinamakan fitrah ${ }^{6}$.

Pertanyaan menariknya adalah dimana sesungguhnya letak alasan bahwa Pancasila itu memiliki basis "spiritualitas-teologis" bersesuaian dengan konsep fitrah dalam Islam, oleh karena pengajuan pertanyaan itu disekitaran basis teologis, maka patut kiranya menghadirkan Pancasila saat mana pidato yang disampaikan oleh Bung Karno pada tanggal 1 Juni 1945, penting meriwayatkan sebuah pengakuan keyakinan theologis dari seorang Bung Karno sebelum melafalkan Pancasila yang menjadi dasar bangunan Indonesia Merdeka.

Bahwa Pancasila dengan jujur diaakui oleh Bung Karno, yang ditulis oleh Yudi Latif, dalam bukunya: Negara Paripurna, Historisitas, Rasionalitas, dan aktulaitas Pancasila: "merupakan Ilham yang diturunkan Tuhan kepadanya, menurut pengakuannya, di malam menjelang tanggal 1 Juni 1945, "ia bertafakkur (menggunakan akal pikirannya dengan sekeras-kerasnya berfikir), menjelajahi lapis demi lapis lintasan sejarah bangsa, menangkap semangat yang bergelorah dalam jiwa rakyat, dan akhirnya menengadahkan tangan meminta petunjuk kepada Allah SWT agar diberi jawaban yang tepat atas pertanyaan tentang dasar negara yang hendak dipergunakan untuk meletakkan Negara Indonesia Merdeka diatasnya, sampai akhirnya didepan sidang BPUPK, Bung Karno mempersembahkan lima mutiara yang 
disebut dengan pancasila itu, diatasnya berdiri Negara Indonesia Merdeka " ( 2011:12).

Bung Karno merekonstruksi gagasan, pikiran dan mengolah bathinnya untuk memproduksi Pancasila sebagai dasar Negara Indonesia Merdeka adalah sebuah Ilham dari Allah SWT, pengakuan tersebut tidaklah bermakna hampar, melainkan sebuah kedekatan yang terus menerus dilakukan oleh Bung Karno, yang didorong oleh kuatnya keyakinan akan kekuasan Maha Tunggal. Karena itu boleh dikatakan bahwa Pancasila tidak dilahirkan diluar kuasa, serta diluar campur tangan skenario Allah kepada Bung Karno, melainkan persis adanya keterlibatan Tuhan dalam pikiran dan lisan Bung Karno untuk disampaikan dalam sidang BPUPK.

Bukan panca Dharma namun dasar ini saya namakan dengan Pantja sila, pantja berarti lima dan sila berarti dasar dan diatas kelima dasar itulah Indonesia didirikan, kekal, dan abadi. Bung Karno menyebut dalam pidato 1 Juni itu pada sila ke lima, Ketuhanan yang berkebudayaan. Prinsip Indonesia merdeka dengan bertaqwa kepada Tuhan Yang Maha Esa bahwa prinsip sila kelima daripada negara kita ialah ke-Tuhanan yang berkebudayaan, ke-Tuhanan yang berbudi pekerti luhur, keTuhanan yang homat menghormati satu sama lain.

Sila Ketuhanan yang berkebudayaan ditempatkan pada sila ke lima oleh Bung Karno memiliki dasar dan alasan teologis, sekiranya Bung Karno tidak memiliki alasan keyakinan ke-Tauhidannya sebagai seorang muslim yang taat maka Bung Karno tidak akan pernah mengakuinya dalam sebuah karyanya "Sarinah Kewajiban Wanita Dalam Perdjoangan Republik Indonesia, mengakui dalam ucapanya bahwa "dan.. entah ini dimengerti orang atau tidak.. saya mencintai sosialisme, oleh karena saya ber-Tuhan dan menyembah kepada Tuhan. Saya mencintai sosialisme oleh karena saya cinta kepada Islam, dan sebagai salah satu ibadah kepada Allah. Didalam cita-cita politikku aku ini nasionalis, di dalam cita-cita sosialku aku ini sosialis, didalam cita-cita sukmaku aku ini sama sekali theis; sama sekali percaya kepada Tuhan, sama sekali ingin mengabdi kepada Tuhan (1947:325).

Keselarasan makna yang terkandung dalam sila Ketuhanan Yang Maha Esa merupakan inti dari cakupan makna fitrah dalam Islam itu sendiri, Ulama Nahdlatul Ulama dalam mengahiri perdebatan polimik dari kalangan nasionalis muslim dan nasionalis sekuler dengan menyatakan bahwa prinsip ke-Tuhanan adalah sila yang mencerminkan Tauhid Islam, mencerminkan berarti membayangkan suatu perasaan, keadaan bathin, dan sebagainya, sila ke-Tuhanan Yang Maha Esa dinilai sudah membayangkan atau menggambarkan apa yang diinginkan oleh Tauhid Islam.

Mengutip Imam Al-Ghazali dalam sebuah tulisannya tentang asal mula kepercayaan bahwa " kepercayaan kepada Allah lahir di dalam diri setiap manusia karena fitrahnya (sifat yang ditanamkan Allah ke dalam diri manusia sewaktu menciptakannya), dan tak seorangpun dapat menghindari dorongan fitrahnya untuk mencari pengetahuan mengenai Allah, lagi pula di dalam al-Qur'an kita jumpai banyak sekali penanda-penanda yang dapat berperan sebagai dasar kepercayaan kepada Allah yang mudah di pahami untuk membuatnya percaya kepada Pencipta Yang Tunggal, yang memerintah dan mengendalikan alam semesta.

Merujuk penjelasan Imam Al-Ghazali ini, dapat dijelaskan pula dalam pandangan penulis bahwa pengakuan yang di lafadzkan lewat lisan yang diverbalkan dalam kata maupun pidato termasuk pidato Bung Karno 1 Juni 1945 tentang dasar negara Indonesia Merdeka, sila yang berke-Tuhanan Yang Maha Esa itu tak lain dan 
tak bukan adalah pantulan dari resonansi bentuk keyakinan terdalam dari sesorang yang meyakini dan menyandarkan seluruh gerak hidupnya hanyalah kepada Tuhan.

Tuhan menjadi titik sentral yang mengkomandai gerak hidup Bung Karno dalam mengalirkan pancasila disela-sela tafakkurnya, menerobos lapisan-lapisan admosfir generasi kegenerasi dalam setiap masa yang dilampuinya. Itulah mengapa dasar Idiologi Bangsa Indonesia Pancasila bertahan dan semoga kesadaran kolektif sebagai anak Bangsa terus mempertahankan Pancasila, karena selain menjadi titik temu keragaman, mempertemukan perbedaan untuk harmoni kehidupan Bangsa, namun pancasila yang terdiri dari lima sila tersebut bersesuaian dengan fitrah penciptaan manusia dalam Islam.

Terutama pada sila ke-tuhanan Yang Maha Esa "Qul huallahu ahad" katakan (Muhammad) Dialah Allah Yang Maha Esa. Atau tepatnya penulis menarasikan sila Ketuhanan Yang Maha Esa adalah bentuk konfirmasi antara keselarasan, kesesuaian, ketersambungan dan tidak adanya perbenturan Pancasila dengan nilai kebenaran yang dikandung kata ke-Fitrahan dalam Islam.

Dan menurut Prof Dr Buya Syakur, MA dalam sebuah kajiannya mengungkapkan bahwa sila pertama merupakan cara pendiri bangsa Indonesia untuk menyatukan berbagai agama yang ada di nusantara yaitu dimaknai sebagai syarat tidak tertulis untuk tinggal di Indonesia siapapun yang ingin tinggal di Negara Indonesia harus mengakui Tuhannya satu, dengan demikian semua agama dipaksa untuk mengakui Tuhan itu Esa. Hal ini dapat diartikan bahwa hubungan seorang manusia dengan Tuhannya merupakan hubungan yang privacy yang bersifat horizontal, masing-masing mempunyai kebebasan meyakini keyakinan nya sendirisendiri dan tidak ada hubungan kerugian bagi satu dengan yang lainnya. Jika hal ini di jadikan pijakan bagi berbangsa dan bernegara seperti di Nusantara ini yang mempunyai ragam suku bangsa dan agama, tentunya tidak akan mengalami kendala dalam menciptakan kedamaian ditengah masyarakat.

Gambar. 1. Hubungan Sila 1-5 Pancasila

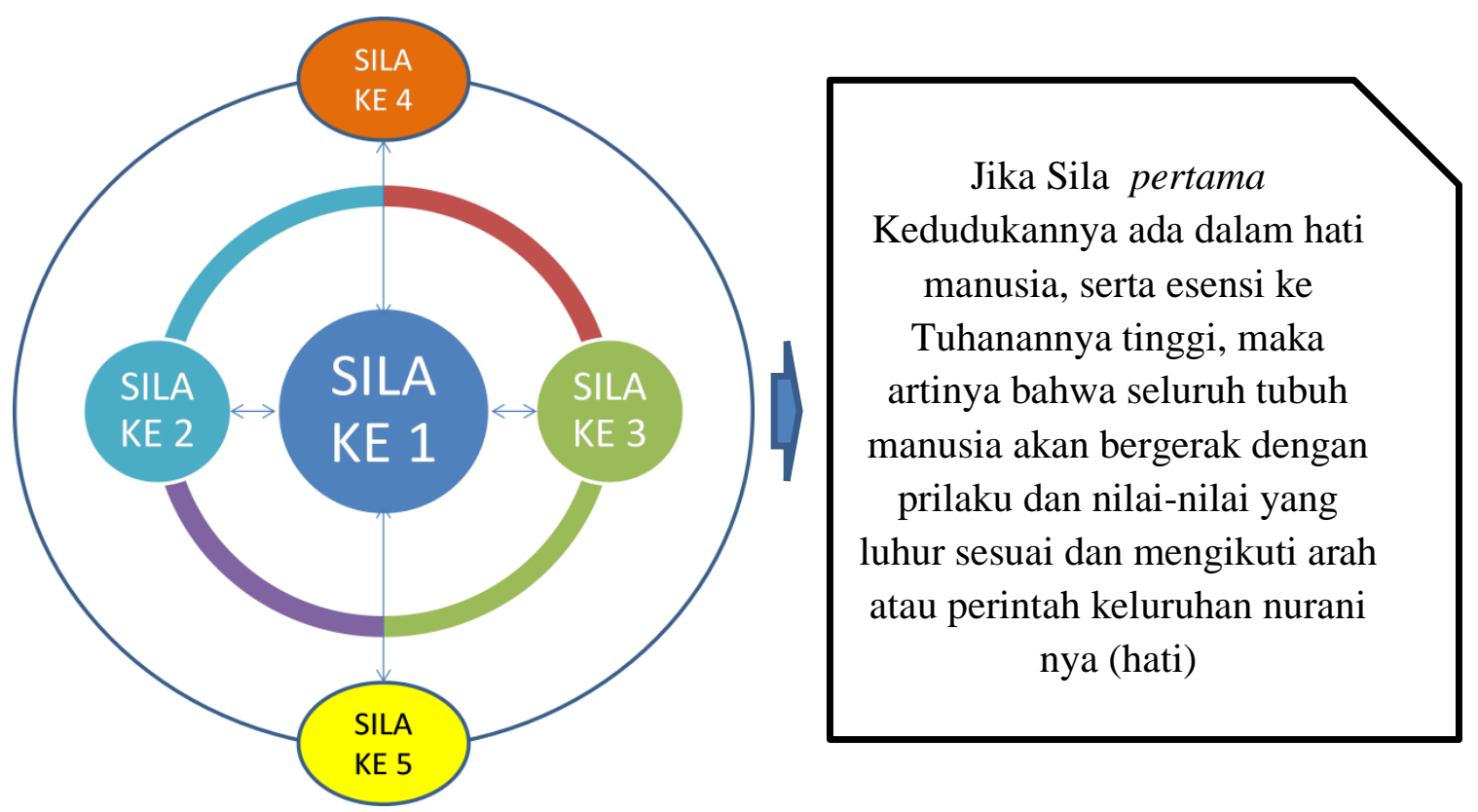

Hubungan sila pertama dengan sila selanjutnya tidak dapat dipisahkan satu dengan yang lainnya, merupakan satu kesatuan yang utuh, seperti tubuh manusia yang 
saling berhubungan antara anggota tubuh satu dengan yang lainnya. Seperti halnya ungkapan Rasulullah saw :

"Ketahuilah sesungguhnya dalam tubuh itu ada segumpal daging, jika daging tersebut baik, maka baiklah seluruh tubuh. Jika rusak, maka rusaklah seluruh tubuh. Ketahuilah, segumpal daging itu adalah hati (jantung)" (HR. al-Buhkari Muslim).

Hal ini tentunya juga merupakan adanya korelasi antara hati dengan seluruh anggota tubuh manusia, sementara keyakinan tentang adanya Tuhan Yang Maha Esa juga merupakan keteguhan sekaligus pengetahuan hati manusia tentang keimanan seseorang. Jika nilai esensi ketuhanan seseorang tinggi maka akan mempengaruhi prilaku, tindakan, serta keputusan-keputusan dari setiap langkah manusia itu sendiri. Maka wajar jika terdapat ajaran dalam Islam bahwa "'Ketahuilah bahwa setiap kamu adalah pemimpin dan setiap pemimpin bertanggung jawab atas kepemimpinannya. Setiap kepala negara adalah pemimpin, dan dia bertanggung jawab atas kepemimpinan (rakyatnya), setiap perempuan/ ibu adalah pemimpin bagi rumah tangga suaminya dan anak- anaknya, ia bertanggung jawab atas kepemimpinannya. Seorang hamba sahaya adalah pemimpin bagi harta tuannya dan bertanggung jawab atas kepemimpinannya. Ketahuilah bahwa setiap kamu adalah pemimpin dan masingmasing bertanggung jawab atas kepemimpinannya" "Dan semua itu tergantung kepada integritas manusia masing-masing dalam mengelola dirinya. Maka wajar sila pertama merupakan titk kordinat yang paling penting, sebab jika manusia sudah ber Tuhan, dan esensi ke Tuhanannya tinggi, maka akan tercermin dalam nilai-nilai pada sila-sila berikutnya untuk menjalankan kehidupan di lingkungan masyarakatnya.

Dalam konsep yang dibuat oleh Let.Jend (Purn) Azwar Anas ${ }^{8}$ dalam gambar 2 di bawah ini bahwa manusia memiliki level tertentu dalam menjalankan ibadah dan prilaku yang sesuai dengan level kesadarannya sebagai manusia yang beriman dan bertaqwa. Cerminan hidup dalam kesehariannya merupakan cerminan kesadarannya sebagai manusia yang beriman dan bertaqwa kepada Allah swt secara langsung maupun tidak langsung. Karena manusia yang sudah pada tahapan habluminallah secara sempurna maka automatically menjalankan habluminannas dengan baik pula dalam lingkungan masyarakatnya. Manusia yang sudah mampu pada levelan tahapan keislaman di setiap level nya, maka manusia tersebut mampu pula menjalankan tugas nya sebagai manusia yang sempurna, berakhlak karimah atau memeiliki budi pekerti sesuai level keimanannya di tengah masyarakat. Untuk dapat menjalankan dan mengamalkan secara seksama isi dari UUD 45 juga tidak lepas dari tuntunan dan pengamalan pada Pancasila, karena UUD dan Pancasila merupakan satu kesatuan yang tidak dapat dipisahkan dalam implementasinya dalam kehidupan bermasyarakat dan bernegara, kemudian keduanya tidak dapat berjalan tanpa adanya kesadaran manusia terhadap Tuhan Yang Maha Esa, yang telah menciptakan manusia dengan berbagai macam suku bangsa, agar dapat hidup rukun sejahtera secara bersama-sama.

\section{Gambar 2. Tingkat Kesadaran Manusia}




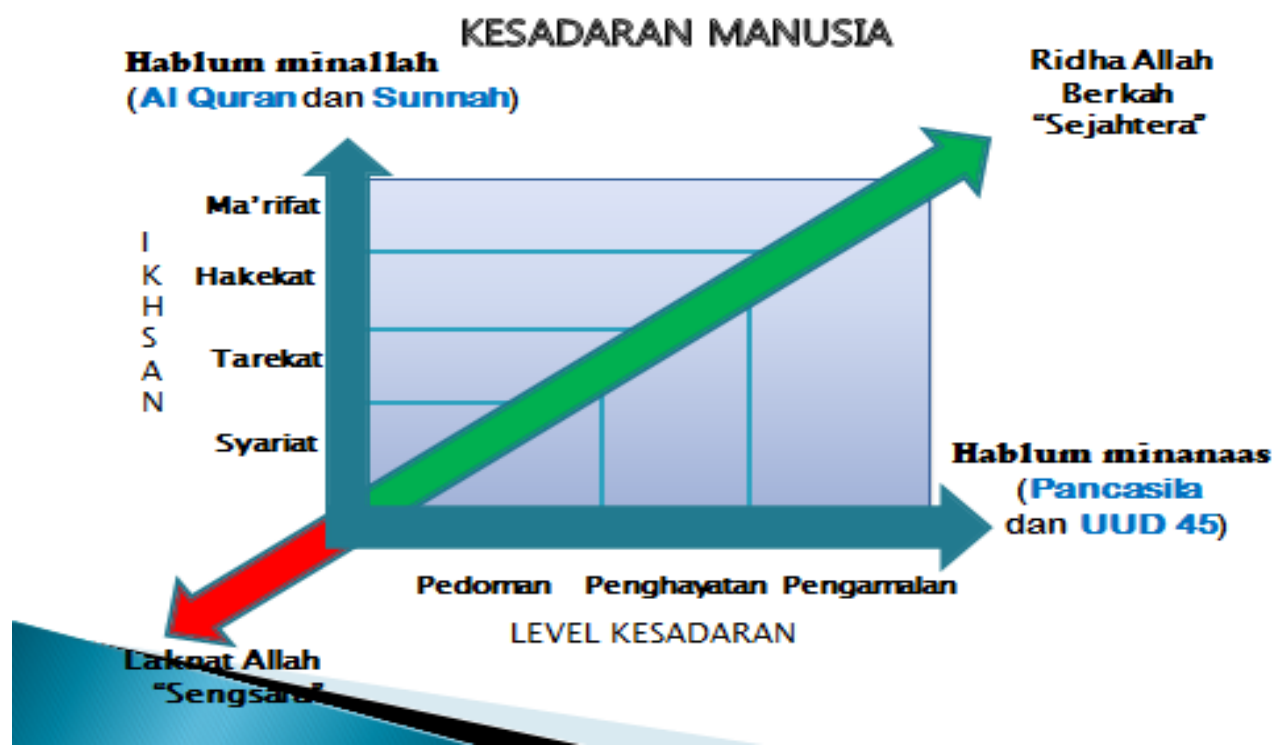

Kemudian daripada itu, Hakekat Manusia secara kodrat, menurut Prof Notonagoro (Guru Besar Uni.Pancasila) : Manusia terdiri dari Jiwa \& Tubuh. Jiwa terdiri atas akal, rasa dan kehendak, Tubuh terdiri dari Unsur binatang, tumbuhan \& benda mati, JIWA \& TUBUH dua hal yg tidak bisa dipisahkan dalam kesatuan. Hal inipun dapat dilihat dalam gambar 3 di bawah ini merupakan gambaran hakekat manusia yang di maksud oleh notonegoro.

\section{Gambar 3. Hakekat Manusia}

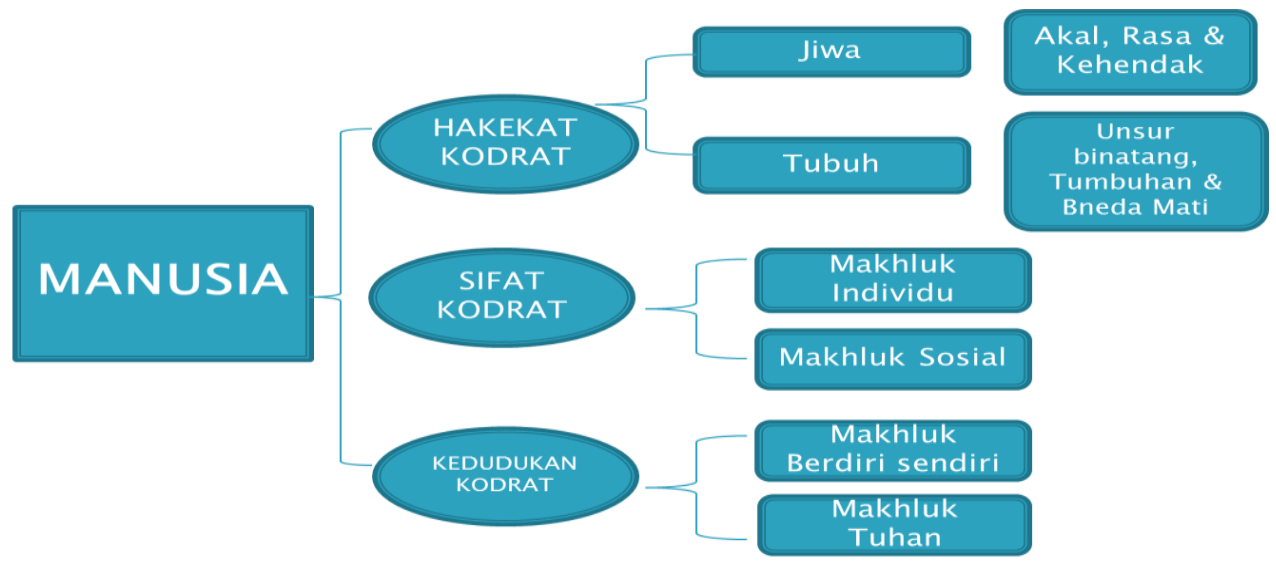

Namun Hakikat manusia menurut Imam Ghazali ${ }^{9}$ adalah individu yang terintegrasi jiwa dan raga, yang memiliki jiwa sebagai penentu hidup dan raga sebagai wadah dari jiwa, jika jiwanya bersih (taqwa) maka raganya bersih (taqwa) dan sebaliknya jika jiwanya kotor (fujur) maka raganya juga kotor (fujur). Hakikat manusia menurut al-Ghazali adalah menjadi seorang yang ma'rifatullah. Pencapaian jiwa ma'rifatullah harus melalui proses pertama, takhalli, kedua, tahalli dan tajalli. Ketiga adalah al-nafs al-muthma'innah yaitu memiliki jiwa yang tenang dan damai untuk selalu bersama dengan zat yang abadi.

Sila ini menurut Ridwan, menekankan fundamen etis-religius atas bangsa Indonesia yang bersumber dari moral ketuhanan dan sekaligus pengakuan akan pluralitas keagamaan. Islam memandang Sila Pertama Pancasila sebagai dasar 
keimanan dan ketauhidan. Menurut Islam bahwa dimensi keimanan terletak pada individu masing- masing. Seseorang tidak diperkenankan melakukan paksaan untuk mengikuti keyakinan tertentu. Demokrasi keagamaan dalam Al-Qur'an dinyatakan secara gamblang dengan pernyataan "tidak ada paksaan dalam agama" (QS. alBaqarah 2: 256). Ayat ini mengandung dua sudut pandang hukum: hukum agama menggarisbawahi menekan manusia agar mengikuti keimanan tertentu dalam situasi terpaksa ${ }^{10}$.

\section{Kemanusiaan Yang Adil Dan Beradab- Hablu Min An-Nâs}

Sila kedua yang berbunyi "Kemanusiaan yang Adil dan Beradab" mencerminkan hubungan antara manusia dengan sesamanya (Hablum Min An-Nâs). Apabila dalam hablum min Allah kedudukan manusia sebagai hamba, maka dalam hablum min an-nâs hubungan manusia dengan sesama manusia, dan berada dalam posisi khalifah fil-ardhi. Dalam isi sila ini berkaitan dengan syari'ah, yaitu termasuk ke dalam ibadah sosial, yang mencakup bidang kemasyarakatan (as-siyasah), yang dalam Islam didasarkan pada sikap saling menghormati. Dalam Al-Qur'an surat AlBaqarah: 177, Allah menjelaskan dengan rinci hakikat berbuat kebaikan, yang dimulai dari ibadah ritual hingga ibadah sosial. "Bukanlah menghadapkan wajahmu ke arah timur dan barat itu suatu kebajikan, akan tetapi sesungguhnya kebajikan itu ialah beriman kepada Allah, hari kemudian, malaikat-malaikat, kitab- kitab, nabi-nabi dan memberikan harta yang dicintainya kepada kerabatnya, anak-anak yatim, orangorang miskin, musafir (yang memerlukan pertolongan) dan orang-orang yang meminta-minta; dan (memerdekakan) hamba sahaya, mendirikan shalat, dan menunaikan zakat; dan orang-orang yang menepati janjinya apabila ia berjanji, dan orang-orang yang sabar dalam kesempitan, penderitaan dan dalam peperangan. Mereka itulah orang-orang yang benar (imannya); dan mereka itulah orang-orang yang bertakwa." Selain itu, dalam Al-Qur'an pun Allah tidak melarang umatnya berbuat baik terhadap orang yang berbeda agama, ini menandakan sikap saling menghormati harus kepada semua kalangan, sesuai degan prinsip rahmatan lil 'alamin.

Sila kemanusiaan yang adil dan beradab dalam Pancasila pada prinsipnya menegaskan bahwa kebangsaan Indonesia merupakan bagian dari kemanusiaan universal, yang dituntut mengembangkan persaudaraan dunia berdasarkan nilai- nilai kemanusiaan yang berkeadilan dan berkeadaban. Kemanusiaa yang adil dan beradab merupakan kesadaran sikap dan perbuatan manusia yang didasarkan pada potensi akal budi dan hati nurani. Yaitu akhlak mulia yang dicerminkan dalam sikap dan perbuatan sesuai dengan kodrat, hakikat dan martabat manusia. Keadaban dan keadilan, menurut Islam adalah bagian inti dari risalah (ajaran). Islam adalah tradisi perdamaian dan harmoni. Harmoni adalah ta'aluf ${ }^{11}$, yakni keakraban (familiarity), kekariban, kerukunan dan kemesraan (intimacy), dan saling pengertian (understanding). Harmoni juga tawafuq, yaitu persetujuan, permufakatan, perjanjian (agreement), dan kecocokan, kesesuaian, keselarasan (conformity). Sila kedua Pancasila juga mengajarkan bagaimana untuk saling menjunjung tinggi nilai-nilai kemanusiaan dengan memperlakukan manusia secara adil dan jujur, sehingga akan melahirkan manusia yang beradab, sopan santun, humanis, baik dalam tindakan maupun ucapan. Sehingga, berdasarkan sila kemanusiaa yang adil dan beradab, kebangsaan yang dikembangkan bukanlah kebangsaan yang menyendiri, bukan chauvinisme (mengagungkan kesukuan atau kedaerahan) melainkan kebangsaan yang berkeluargaan antar bangsa-bangsa. Sehingga konsepsi ini sejalan dengan visi Jajat Burhanudin dan Kees Van Djik, (Ed), Islam in Indonesia; Contrasting Images and 
Interpretations (Amsterdam, Amsterdam University Press, 2011). Menurut Yudi Latif $^{12}$, Sila Kedua Pancasila adalah cerminan nilai-nilai kemanusiaan universal yang bersumber dari hukum Tuhan, hukum alam, dan sifat-sifat sosial manusia (horizontal) dianggap penting sebagai fundamen etika-politik kehidupan bernegara dalam pergaulan dunia. Prinsip tersebut dikembangkan melalui dua jalur, yaitu eksternalisasi dan internalisasi. Secara eksternalisasi bangsa Indonesia menggunakan segenap daya dan khazanah yang dimilikinya untuk secara bebas-aktif "ikut melaksanakan ketertiban dunia yang berdasarkan kemerdekaan, perdamaian abadi dan keadilan sosial". Sedang secara internalisasi bangsa Indonesia mengakui dan memuliakan hakhak dasar warga dan penduduk negeri. Landasan etik sebagai prasyarat persaudaraan universal ini adalah "adil" dan "beradab".

Perbedaan itu bukanlah suatu masalah jika memiliki hati yang baik dan takwa, tentunya tidak hanya secara vertikal, yakni antara manusia dengan Sang Pencipta, tetapi juga secara horizontal, yakni antara manusia dengan manusia yang lain. Imam al-Ghazali, dalam kitab Bidâyatul Hidâyah menjelaskan bahwa ada tiga kategori golongan manusia, dilihat dari cara mereka bergaul dan bersosialisasi dengan sesama manusia. Al-Ghazali menyebutkan bahwa dalam hubungan sesamanya, manusia terbagi menjadi tiga golongan.

Pertama, manusia yang tergolong dalam derajat yang mulia sebagaimana derajatnya para malaikat. Menurut Imam al-Ghazali, orang-orang yang termasuk dalam kategori ini senantiasa berbuat baik dengan sesama manusia, tidak hanya berbuat baik, mereka juga senantiasa memberikan kebahagian kepada sesama. Tidak hobi menyakiti orang lain, juga tidak suka berperilaku menyimpang kepada orang lain. Golongan manusia seperti inilah yang disebut Imam al-Ghazali sebagai golongan yang termasuk "Manzilatul kirâm al-bararah minal malâikah", yakni golongan manusia yang sikapnya setara dengan golongan malaikat yang saleh.

Kedua, manusia yang setara dan sederajat dengan hewan dan benda-benda mati. Oleh al-Ghazali disebut setara dengan hewan dan benda mati, karena keberadaannya tidak memberikan dampak dan manfaat bagi orang lain, tetapi malah memberikan madharat dan bahaya bagi orang lain. Sebagaimana benda-benda mati, ia hanya stagnan, tidak bergerak, dan pula tidak memberikan dampak yang signifikan bagi kehidupan manusia yang lain. Sedangkan golongan yang terakhir adalah golongan yang sama dengan golongan hewan-hewan buas, seperti ular, kalajengking dan hewan-hewan berbahaya yang lain. Menurut penulis Ihyâ' Ulûmiddin ini, manusia yang termasuk golongan ini menjadi momok bagi manusia lain. Tidak ada kebaikan yang bisa diharapkan, dampak bahayanya sangat dikhawatirkan. Diakui atau tidak, dalam kehidupan bermasyarakat, pasti kita temukan orang-orang yang seperti ini, baik golongan pertama kedua maupun ketiga. Imam al-Ghazali menyarankan agar kita bergaul dan berinteraksi dengan golongan yang pertama, agar kita tidak mendapatkan bahaya. Imam al-Ghazali juga menyarankan agar kita senantiasa berusaha untuk menjadi bagian kelompok pertama. Jika kita tidak mampu, berusahalah agar tidak menjadi golongan kedua maupun ketiga.

Allah juga tidak melarang kamu untuk berbuat baik dan berlaku adil terhadap orang-orang yang tiada memerangimu karena agama dan tidak (pula) mengusir kamu dari negerimu. Sesungguhnya Allah menyukai orang-orang yang berlaku adil. (Q.S. Al- Mumtahanah: 8) Kemudian pada ayat lain juga disebutkan,

"Hai manusia, Sesungguhnya Kami menciptakan kamu dari seorang laki-laki dan seorang perempuan dan menjadikan kamu berbangsa - bangsa dan bersuku-suku 
supaya kamu saling kenal-mengenal. Sesungguhnya orang yang paling mulia di antara kamu di sisi Allah ialah orang yang paling taqwa di antara kamu. Sesungguhnya Allah Maha mengetahui lagi Maha Mengenal." (Q.S. Al-Hujurât: 13).

Sikap saling mengenal pada perintah ayat di atas maksudnya yaitu jika sesama manusia saling mengenal, maka akan timbul sikap saling hormatmenghormati. Salah satu cara manusia untuk mengenal yaitu dengan berdialog. Dialog dapat memunculkan keterbukan berbagai pihak, yang pada akhirnya akan timbul sikap saling mengetahui satu sama lain, dan juga melahirkan sikap saling menghomati. Sehingga di sinilah letak beradabnya manusia. Ayat 13 di dalam Q.S AlHujurât tersebut juga memberikan satu landasan tindakan kemasyarakatan umat Islam, bahwa dalam pergaulan kemasyarakatan dan hubungan antarbangsa, umat Islam tidak mungkin melepaskan tanggung jawabnya, yang secara khusus di dalam membangun kerja sama, saling mengerti dan menghargai satu sama lain. ${ }^{13}$

Jika kita menolak semangat yang terkandung dalam sila kedua dari Pancasila ini, berarti dengan sendirinya kita menolak menjalin hubungan baik dengan manusia secara beradab dan berakhlak. Konsekwensi logisnya, kalau kita menolak berhubungan baik dengan manusia, sebutan yang pas untuk kita ialah manusia tak bermoral, barbar dan biadab. Na'udzu billah!Dalam al-Quran, banyak sekali ayat-ayat yang berbicara mengenai posisi manusia dan kemanusiaan. Hal demikian misalnya seperti yang dapat kita perhatikan pada QS. At-Taghabun: 3, Hud: 61, Ibrahim: 3234, Luqman: 20, ar-Rahman: 3-4, al-Hujurat: 13, al-Maidah: 32 dan lain-lain. Membunuh manusia hanya karena alasan mereka kafir, musyrik menurut pandangannya jelas sangat bertentangan dengan ayat ini. Nabi saja diutus untuk menyempurnakan akhlak manusia agar mereka menjadi manusia seutuhnya. Jika ada seorang muslim yang tidak memiliki sifat perikamanusiaan, maka dia bertentangan dengan al-Quran dan hadis nabi. Dalam hadis-hadisnya, Nabi sering mendefinisikan seorang muslim sebagai man salima al-muslimun min yadihi wa lisanihi "orang yang mampu menjaga lidah dan tangannya untuk tidak menyakiti sesama." Jadi orang yang tidak menjaga lidah dan tangannya, layak disebut sebagai bukan muslim. Artinya sebagai manusia muslim yang baik kita harus berperikemanusiaan.

\section{Persatuan Indonesia (Ukhuwah)}

Sila ketiga yang berbunyi "Persatuan Indonesia" mencerminkan ide ukhuwah insaniyah (persaudaraan manusia) ${ }^{14}$ dan ukhuwah Islamiyah bagi sesama umat Islam. Allah berfirman dalam Al-Qur'an Surat Ali Imran ayat 103 dan 105,

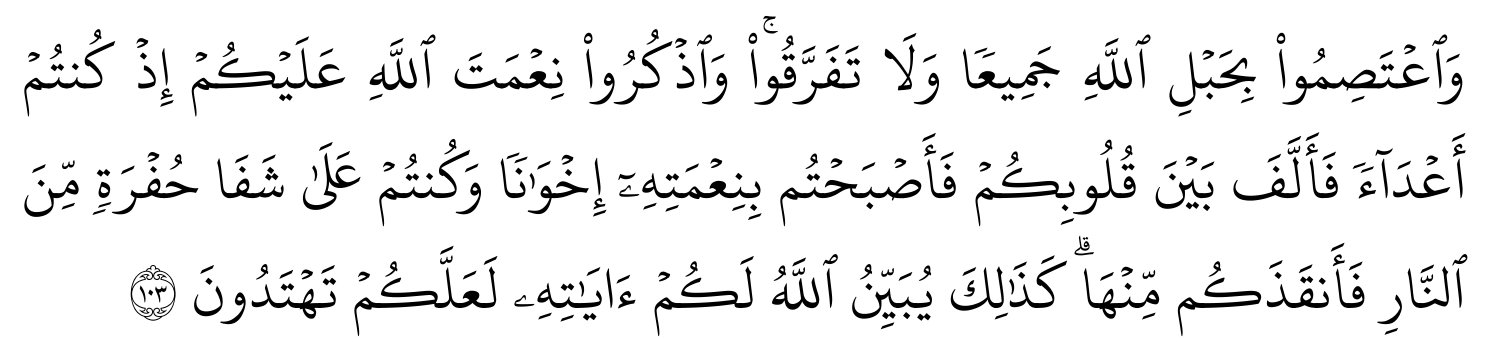

"Berpeganglah kamu semuanya kepada tali (agama) Allah, dan janganlah kamu bercerai berai, dan ingatlah akan nikmat Allah kepadamu ketika kamu dahulu (masa Jahiliyah) bermusuh-musuhan, Maka Allah mempersatukan hatimu, lalu menjadilah kamu karena nikmat Allah, orang-orang yang bersaudara; dan kamu telah berada di tepi jurang neraka, lalu Allah menyelamatkan kamu dari padanya. Demikianlah Allah menerangkan ayat-ayat-Nya kepadamu, agar kamu mendapat petunjuk.” (QS. Al-Imran: 103) 


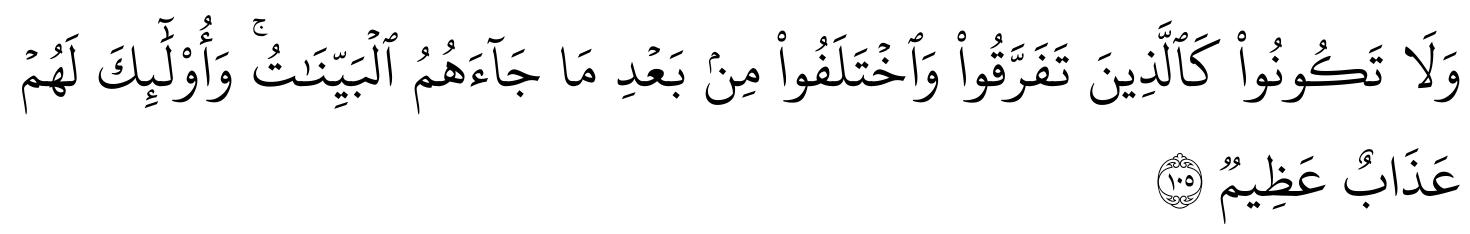

"Janganlah kamu menyerupai orang-orang yang bercerai-berai dan berselisih sesudah datang keterangan yang jelas kepada mereka. mereka Itulah orang-orang yang mendapat siksa yang berat". (QS. Al-Imran:105)

Persatuan akan terwujud apabila telah terjadi sikap toleransi yang tinggi antar sesama, sikap saling menghargai dan menghormati. Selain itu, dalam persatuan harus ditarik sifat persamaannya, bukan perbedaan yang hanya akan menimbulkan perselisihan dan pertentangan. Persatuan yang perlu digarisbawahi yaitu sama halnya dengan pluralitas. Dalam hal ini pluralitas berdasarkan apa yang dituntut oleh kemaslahatan rakyat, agar tercapai kesatuan dalam tujuan dan sasaran. Tujuan penting tersebut ialah agar umat seluruhnya berdiri dalam satu barisan di hadapan musuhmusuh. ${ }^{15}$

Indonesia adalah sebuah negara besar yang mewadahi warisan kejayaan peradaban Nusantara dan kerajaan-kerajaan bahari tersebar di muka bumi. Oleh sebab itu sangatlah penting untuk menyadari bahwa alasan utama lahirnya bangsa ini adalah adanya kesadaran bersama dan kepentingan bersama untuk hidup rukun. Seperti yang dinyatakan oleh Yudi Latif (2011:376) bahwa dalam mentransformasikan ke-KAMI-an menuju ke-KITA-an, diperlukan sikap positif dan prasangka baik. Kerja sama dan sikap saling memercayai serta itikad baik masingmasing komunitas,yang diperkuat oleh jalinan gotong royong secara fungsional antara pelbagai unsur kelembagaan kemasyarakatan yang ada merupakan segi penunjan efesiensi demokrasi dalam suatu masyarakat multikultur. Sebagaimana yang dinyatakan oleh Nurcholis Madjid (1195: 67) bahwa masyarakat yang terkotak-kotak dengan masing masing penuh curiga kepada satu sama lainnya bukan saja mengakibatkan tidak efesiennya cara hidup demokratis, tapi juga dapat menjurus kepada lahirnya pola tingkah laku yang bertentangan dengan nilai-nilai asasi demokrasi.

Pengakuan akan kebesan nurani (freedom of conscience), persamaan hak dan kewajiban bagisemua (egalitarianism), dan tingkah lakupenuhpercaya kepada tikad baik kepada orang lain dan kelompok lain mengharuskan adanya landasan pandangan kemanusiaan yang positif dan optimis. Sependapat dengan pandangan yang dipaparkan oleh Yudi Latif bahwa untuk membentuk serta menguatkan persatuan maka perlu sikap dan perasangka yang baik sebab tanpa hal itu maka mustahil terciptanya suasana kedamaian antar masyarakat bahkan dapat nmenjelma menjadi phobia bertetangga dan halite menyalahi kodrat dari esensi serta hakikat dari nilainilai Pancasila yang mengutamakan kekeluaragaan dan kerukunan antar sesame manusia terlebih lagi dengan sesawa warga Indonesia. Hal inipun diperkuat oleh pendapat Nurcholis Majid yang mengatakan bahwa jika hidup saling mencurigai maka tidak akan melahirkan efektifnya dari kehidupan yang demokratis.hal inipun dapat berpotensi untuk tidak terjalinnya kekerabatan antar masyarakat dan menyalahikodrat lahirnya bangsa ini yang diamana alasan utamanya adalah adanya kesadaran bersama bahwa ingin hidup rukun dengan satu tujuan.

Menurut Kaelan (2013:276), dalam praktek tumbuh dan berkembangnya persatuan suatu bangsa terdapat dua aspek kekuasaan yang mempengaruhi yaitu 
kekuasaan pisik (lahir) atau disebut juga kekuasaan materialis yang berupakekerasan dan paksaan. Kekuasaan idealis yang berupa nafsu psikis, moral, ide-ide dan kepercayaan-kepercayaan. Proses nasionalisme (persatuan) yang dikuasai oleh kekuasaan fisik akan tumbuh berkembang menjadi bangsa yang bersifat materialis. Sebaliknya proses nasionalisme yang dalam pertumbuhannya dikuasai oleh kekuasaan bathin (kejiwaan) maka akan tumbuh berkembang menjadi negara utopis idealis yang jauh dari realitas bangsa dan negara oleh karena itu bagi bangsa Indonesia prinsipprinsip persatuan itu tidak bersifat berat sebelah, namun justru merupakan sintesis yang serasi dan harmonis baik hal-hal yang bersifat lahir maupun hal-hal yang bersifat bathin. Prinsip tersebut adalah yang paling susuai dengan hakikat manusia yang bersifat monopluralis, yang terkandung dalam Pancasila.

Menurut Yudi Latif ${ }^{16}$ bahwa sila Ketiga Pancasila memberikan arti kuat pada aktualisasi nilai-nilai etis kemanusiaan yang harus mengakar kuat dalam lingkungan kebangsaan. Dengan demikian, Indonesia memiliki prinsip dan visi kebangsaan yang kuat, bukan saja dapat mempertemukan kemajemukan masyarakat dalam kebaruan komunitas politik bersama, tetapi juga mampu memberi kemungkinan bagi keragaman komunitas untuk tidak tercerabut dari akar tradisi dan kesejarahannya masing-masing. Inilah konsepsi persatuan Indonesia yang mengatasi paham golongan dan perseorang. Dengan mengedepankan persatuan dari kebhinekaan masyarakat, Indonesia dikelola berdasarkan konsepsi kebangsaan yang mengekspresikan persatuan dalam keragaman dan keragaman dalam persatuan.

Menurut Prof. Dr. Buya Syakur, MA bahwa factor beraneka ragamnya bahasa, adat, geografis, agama, merupakan kehendak Allah swt, seperti terjadinya perang bubat pada masa majapahit. Kemudian saat kemerdekaan muncul pertanyaan pada Dasar Negara, yang akhirnya menjadi suatu perdebatan antar umat. Saat itu Jepang meminta syarat kepada bapak Soekarno untuk menghapus 7 kata yaitu "melaksanakan syariatnya." Bapak Soekarno pada saat itu berjanji kepada umat Islam setelah merdeka akan kita bahas lagi, saat ini yang penting merdeka dulu dan penuhi syarat Jepang. Menurut Prof. Dr Syakur MA ${ }^{17}$ juga dalam kajiannya di acara Hari Ulang Tahun Kemerdekaan Indonesia yang Ke-74 mengatakan bahwa: "Beruntunglah dasar Negara kita adalah Pancasila, maka kita terhindar dari kehancuran yang sama dengan Negara-negara Islam lainnya di dunia." Rasulullah saw saat itu betul-betul telah berhasil dalam melakukan kesatuan dan persatuan antara anshor dan muhajirin dan tidak ada lagi kecuali oleh nabi saat itu, karena visi misi Rasulullah sendiri hanya menegakkan kalimat tauhid bukan untuk memetong tangan orang, dan kalimat tauhid tersebut di maknai oleh Rasulullah saat itu adalah "Persatuan." Platform nabu Muhammad saat itu adalah persatuan, yang kemudian menjadi tokoh persatuan. Syariat-syariat yang di bangun adalah persatuan, dan maqosid syariah yang diterapkan Rasulullah saw dalam rangka membangun persatuan umat. Kemudian Prof. Dr. Buya Syakur MA juga mengulas tentang gerakan pecah belah Indonesia saat ini, yaitu tentang munculnya radikalisme, sparatisme, perang sudara antar sesame muslim karena Indonesia mayoritas muslim, Negara itu seharusnya Negara bertuhan bukan Negara beragama, bersama-sama membangun kebaikan dan berdakwah membangun social yang dapat mendamaikan semua pihak.

Dari pendapat diatas sangatlah jelas bahwa bangsa yang mengisi kemerdekaan dengan hal positif yakni larutnya kekuasaan fisik oleh kekuasaan jiwa. Sebab domain jiwa adalah pengontrol segala hal yang bersifat lahiriyah yang tidak aka ada batasnya sehingga perlu dilandasai kekuatan bathin agar dapat merasakan kehendak orang lain yang penuh pula dengan kepentingan sehingga jika kedua elemen dapat harmonis 
maka akan mampu mengokohkan semangat berbangsa dan bernegara yang berlandaskan kekeluargaan tanpa memarjinalkan sekelompok masyarakat bahkan individu. Jaman yang terus berkembang memasuki era globalisasi, tidak menutup kemungkinan adanya budaya luar yang masuk ke dalam negara ini dan melebur dalam kebudayaan bangsa. Hal itu juga merupakan ancaman tersendiri bagi suatu negara untuk menghadapi suatu konflik perpecahan di dalam negara. Sekarang banyak budaya Indonesia yang sudah mulai terlupakan di kalangan muda. Tanpa disadari mereka lebih banyak menggunakan budaya asing dalam kehidupannya, dan gaya hidupnya. Oleh karena itu, sebaiknya bangsa Indonesia tetap menjaga persatuan yang ada dalam negara ini. Walaupun banyak perbedaan tetapi tetaplah satu kesatuan dalam negara Indonesia. Perlu untuk memulihkan kesadaran dari makna sila ketiga "Persatuan Indonesia" dalam pribadi masyarakat Indonesia agar masyarakat Indonesia menyadari betapa pentingnya persatuan dalam suatu kehidupan berbangsa dan bernegara demi tetap menjaga persatuan. Menurut Syahrial Syarbaini, Implementasi sila Persatuan Indonesia dalam kehidupan sosial budaya dapat dilakukan melalui ${ }^{18}$ beberapa bidang:

1. Bidang Pendidikan Pendidikan adalah salah satu piranti untuk membentuk kepribadian. Penanaman kepribadian yang baik harus dilakukan sejak dini.Terutama penanaman rasa cinta tanah air dan rasa persatuan dan kesatuan sebagai bangsa Indonesia. Kepribadian yang baik para penerus bangsa akan menentukan nasib dan kemajuan Indonesia di masa mendatang. Nilai-nilai Pancasila harus ditanamkan kuat pada generasi-generasi penerus bangsa.Tujuan pendidikan nasional adalah menciptakan manusia yang beriman, bertaqwa, berakhlak mulia, sehat, berilmu, cakap, kreatif, mandiri, demokratis, dan bertanggung jawab.

2. Ilmu pengetahuan dan teknologi Iptek harus memenuhi etika ilmiah, yang paling berbahaya adalah yang menyangkut hidup mati, orang banyak, masa depan, hakhak manusia dan lingkungan hidup. Di samping itu Ilmu pengetahuan dan teknologi di Indonesia harus sesuai dengan nilai-nilai Pancasila karena Iptek pada dasarnya adalah untuk kesejahteraan umat manusia. Nilai-nilai Pancasila sila ketiga bilamana dirinci dalam etika yang berkaitan dengan ilmu pengetahuan dan teknologi, adalah sebagai berikut:

a. Sumber ilmiah sebagai sumber nasional bagi warga negara seluruhnya.Pemanfaatan ilmu pengetahuan dan teknologi harus mendahulukan kepentingan bangsa dan negara.

b. Alokasi pemerataan sumber dan hasilnya.

c. Pentingnya individualitas dan kemanusiaan dalam catur dharma ilmu pengetahuan, yaitu penelitian, pengajaran, penerapan, dan pengamalannya.

d. Persaingan IPTEK tidak untuk saling menjatuhkansatu sama lain. Namun penemuan- penemuan baru yang membantu kegiatan manusia dan mempermudah pekerjaan manusia adalah untuk satu tujuan yakni guna kemajuan negara Indonesia. Dalam mengakualisasikan sila Persatuan Indonesia dalam bidang sosial budaya dapat dipertimbangkan beberapa prinsip pemikiran implementatif, antara lain:

1) Mampu menempatkan persatuan, kesatuan, serta kepentingan dan keselamatan bangsa dan negara sebagai kepentingan bersama di atas kepentingan pribadi dan golongan.

2) Sanggup dan rela berkorban untuk kepentingan negara dan bangsa apabila diperlukan.

3) Mengembangkan rasa cinta kepada tanah air dan bangsa. 
4) Mengembangkan rasa kebanggaan berkebangsaan dan bertanah air Indonesia.

5) Memelihara ketertiban dunia yang berdasarkan kemerdekaan, perdamaian abadi dan keadilan sosial.

6) Mengembangkan persatuan Indonesia atas dasar Bhinneka Tunggal Ika.

7) Memajukan pergaulan demi persatuan dan kesatuan bangsa. Dalam hal implementasi Pancasila, sependapat dengan pandangan diatas bahwa dalam mewujudkannya dapat melalui istrumen pendidikan dan teknologi yang dilaksanakan dengan bijaksana. Sebagaimana kita ketahui bahwa the founding fathers telah menempatkan tujuan nasional yang sangat visioner sebab telah menyadari betul bahwa yang mampu melarutkan egoisme primordial bangsa ini hanyalah pendidikan sehingga memiliki visi untuk mencerdaskan bangsa. Dengan segala tujuan pendidikan yang mulia dipercaya mampu mendewasakan manusia dan mempersatukan segala perbedaan dan memperlakukan segala perbedaan sebagai suaku kekayaan sosial budaya dan kekuatan identitas nasional bagi bangsa Indonesia serta dalam hal penggunaan teknologi dalam menyonsong percaturan globalisasi yang penuh dengan kecanggihan tentu berpotensi memecah belah bahkan menghancurkan nilai budaya maupun kearifan lokal jika kitatidakmampu menguasai teknologi. Oleh sebab itu, teknologi merupakan salah satu hal yang dapat mengenalkan identitas nasional dan mengukuhkan persatuan bangsa dengan segala informasi yang dapat menyatuhkan negara kesatuan Republik Indonenesia.

Hal ini juga sejalan dengan pemikiran Let.Jend Azwar Anas ${ }^{19}$ dalam skema di bawah ini, bahwa semua komponen bangsa merupakan pondasi utama Bangsa dan Negara Kesatuan Indonesia. Semuanya harus berjalan seiring dan sejalan agar terciptanya keseimbangan dalam menyikapi seluruh perbedaan.

\section{Gambar 4. Pondasi Bangsa}

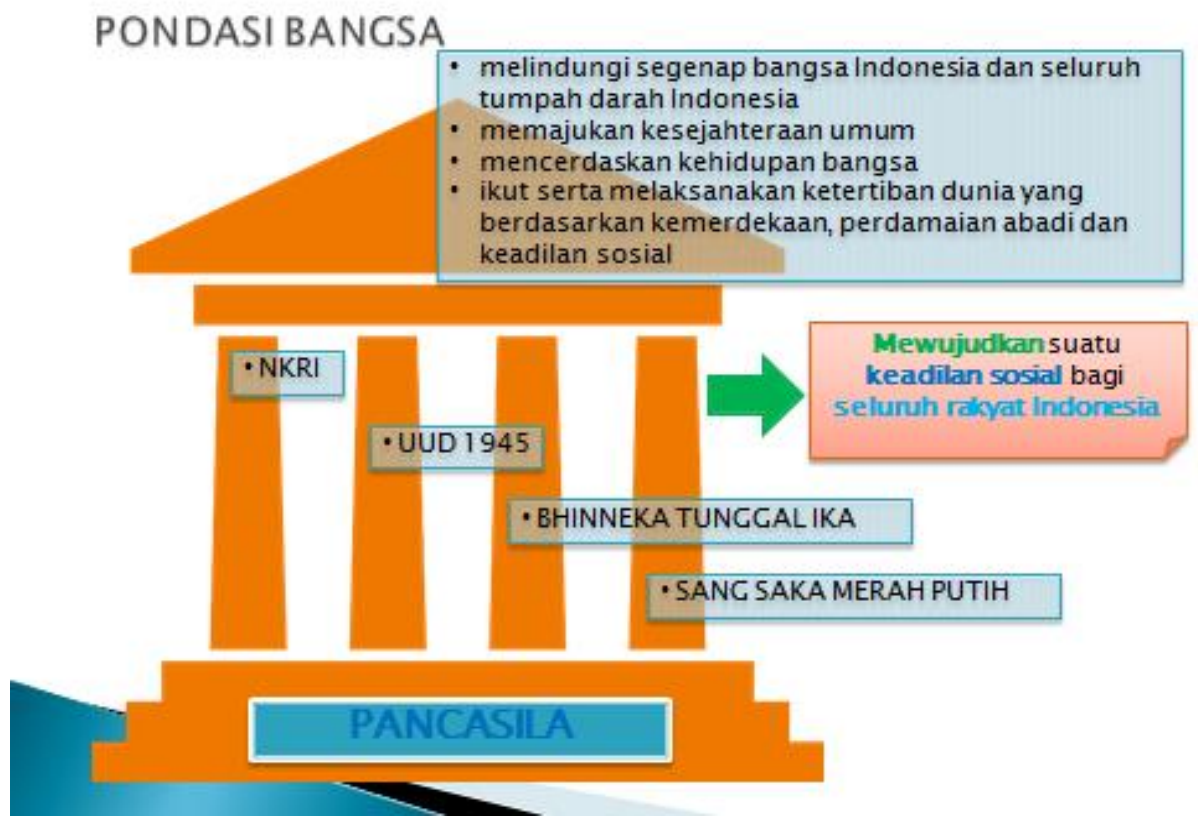

Untuk dapat mewujudkan keadilan social bagi seluruh rakyat Indonesia tersebut dibutuhkan pemahaman dan kesadaran kita sebagai makhluk Tuhan Yang Maha Esa, untuk selanjutnya mampu menjalankan apa yang menjadi pondasi bangsa dan Negara 
dalam melakukan persatuan dan kesatuan dari berbagai perbedaan yang muncul dikehidupan bermasyarakat dan bernegara. Wadah tersebut ada dalam Pancasila yang merupakan pondasi utama bagi keragaman suku, bahasa, agama, budaya, ras dan golongan masyarakat Indonesia.

\section{Mudzakarah (Perbedaan Pendapat) Dan Syura (Musyawarah)}

Sila keempat berisi "Kerakyatan yang Dipimpin oleh Hikmat Kebijaksanaan dalam Permusyawaratan/Perwakilan, yang sejalan dengan prinsip Islam yaitu Mudzakarah dan Syura. Prinsip syura merupakan dasar dari sistem kenegaraan Islam (karakteristik negara Islam). Uniknya, prinsip syura ada di dalam Pancasila. Ini membuktikan bahwa perumusan Pancasila di ambil dalam bentuk musyawarah bersama berbagai kalangan untuk mencapai kesepakatan. Dalam Al-Qur'an Surat Ali Imran ayat 159 :

"Maka disebabkan rahmat dari Allah-lah kamu berlaku lemah lembut terhadap mereka. Sekiranya kamu bersikap keras lagi berhati kasar, tentulah mereka menjauhkan diri dari sekelilingmu. Karena itu maafkanlah mereka, mohonkanlah ampun bagi mereka, dan bermusyawarahlah dengan mereka dalam urusan itu."

Sejalan pula dengan Q. S. Asy-Syuura': 38 “(bagi) orang-orang yang menerima (mematuhi) seruan Tuhannya dan mendirikan shalat, sedang urusan mereka (diputuskan) dengan musyawarah antara mereka..."

Makna alternatif yang diterangkan oleh para mufassir adalah bahwa Rasulullah saw. memerintahkan untuk melakukan musyawarah bukan karena beliau membutuhkan pendapat mereka, melainkan karena ketika beliau menanyakan pendapat mereka, setiap orang akan berusaha berpikir keras untuk merumuskan pendapat yang terbaik dalam pandangan mereka, sehingga sesuai dengan suara hati masing-masing. ${ }^{20}$ Sedangkan pada prinsip Mudzakarah, dimaksudkan sebagai suatu sikap penghargaan terhadap pendapat orang lain yang satu sama lain cenderung berbeda. Namun dengan prinsip ini, dikembalikan lagi kepada rasa persamaan dan kesetaraan, bahwa tidak ada pihak yang merasa lebih tinggi dari yang lain, karena setiap jiwa memiliki hak dan kewajiban yang sama di hadapan Allah dan di depan hukum Negara. Semangat yang terkandung dalam sila keempat ialah semangat untuk melawan segala bentuk tirani yang terejawantahkan ke dalam sistem totalitarianisme dan otoritarianisme dalam pemerintahan. Semangat melawan tirani ini jelas semangat yang qur'ani, karena Islam menolak dengan tegas kekuasaan yang terpusat kepada individu atau segelintir elit tertentu. Kekuasaan yang terkumpul pada satu individu tertentu sangat rawan untuk disalahgunakan dan rawan dari kekeliruan dalam mengambil keputusan dan kebijakan. Dalam al-Quran ilustrasi tentang pemusatan kekuasaan dan kebenaran hanya pada satu sosok tertentu terletak pada model kepemimpinan Fir'aun.

Untuk menghindari itu, al-Quran membuka kanal berupa musyawarah dan pembagian tugas dan wewenang (kullukum ra'in) sebagai solusi agar kekuasaan tidak terpusat kepada satu sosok pemimpin. Nabi dalam QS. Qaf: 45 sering disebut sebagai wa ma anta alayhim bi-jabbar "Kamu bukanlah tipe orang yang bertindak semena-mena terhadap mereka" dan dalam QS. al-Ghasyiyah: 22 lasta alayhim bimusaytir "Kamu bukanlah tipe orang yang otoriter". Dua ayat ini cukup untuk dijadikan rujukan bahwa dalam Islam, tipe kepemimpinan yang otoriter sangatlah dilarang. Ditambah lagi dengan penegasan untuk selalu bermusyawarah seperti yang dapat dilihat pada QS. al-Baqarah: 233, Ali Imran: 159 dan as-Syura: 38 dan 
semangat pembagian kerja atau perwakilan seperti yang dapat kita temukan pada QS. an-Nisa: 35 dan QS. Yusuf: 55.

\section{Keadilan (al-‘adalah) : Keadilan Sosial Bagi Seluruh Rakyat Indonesia}

Sila kelima berisi "Keadilan Sosial bagi Seluruh Rakyat Indonesia", sejalan dengan prinsip keadilan dalam Islam. Lebih spesifikasi lagi, bahwa keadilan yang dimaksud yaitu dalam pemerataan rizki, berupa zakat, infak dan shadaqah. Keadilan sosial berkaitan erat dengan maqashid al-syari'ah (sasaran-sasaran syari'at). Sedangkan maqashid al-syari'ah terdiri dari tiga aspek, yaitu: ${ }^{21}$

a. Dharuriyat, mengenai perlindungan terhadap hal-hal yang bersifat esensial bagi kehidupan manusia, seperti agama/ad-dien, jiwa/nafs, keturunan/nasb, akal/‘aql, dan harta benda/mal.

b. Hajiyat, yaitu pemenuhan hal-hal yang diperlukan dalam hidup manusia, tetapi bobotnya di bawah kadar dharuriyat.

c. Tahsiniyat, yaitu perwujudan hal yang yang menjamin peningkatan kondisi individu dan masyarakat sesuai dengan tuntutan tempat dan waktu, tuntutan selera, dan rasa kepatutan untuk mengelola persoalan- persoalan masyarakat dengan sebaik- baiknya. Dalam prinsip keseimbangan kehidupan ekonomi, AlQur'an mencela orang yang sibuk memupuk harta hingga melupakan kematian. Seperti dalam surat Al-Humazah ayat 1-4,

"Kecelakaanlah bagi Setiap pengumpat lagi pencela, yang mengumpulkan harta dan menghitung- hitungnya, ${ }^{22}$ dia mengira bahwa hartanya itu dapat mengkekalkannya, sekali-kali tidak! Sesungguhnya dia benar-benar akan dilemparkan ke dalam Huthamah (neraka)." Akan tetapi Al-Qur'an tidak melarang orang untuk mencari kekayaan dengan wajar. Allah swt berfirman, "Dan janganlah orang-orang yang mempunyai kelebihan dan kelapangan di antara kamu bersumpah bahwa mereka (tidak) akan memberi (bantuan) kepada kaum kerabat(nya), orang-orang yang miskin dan orang-orang yang berhijrah pada jalan Allah, dan hendaklah mereka mema'afkan dan berlapang dada. Apakah kamu tidak ingin bahwa Allah mengampunimu? Dan Allah adalah Maha Pengampun lagi Maha Penyayang”. Untuk itulah, Islam mewajibkan zakat (Q.S. Adz-Dzariyat: 19), memerintahkan shadaqah (Q.S. AlBaqarah: 264), menyuruh infaq (Q.S. Al-Baqarah: 195), melarang praktek riba atau bunga (Q.S. Al-Baqarah: 275-276 dan 278), serta membolehkan jual beli (Q.S. ArRahman: 9).

Sila kelima dalam Pancasila sangat menjunjung tinggi keadilan, semangat yang selalu digaungkan al-Quran dalam berbagai ayat-ayatnya. Dalam al-Quran, menjunjung tinggi keadilan merupakan bentuk amal yang dekat dengan ketakwaan. Ayat-ayat yang berbicara mengenai keadilan dapat dilihat pada QS. An-Nisa: 58, 135, al-Maidah: 8, al-An'am: 152-153, al-A'raf: 29, Hud: 84-86 dan lain-lain. Begitupun isi yang terkandung dalam UUD 45 yang bersemangat anti-penindasan dan penjajahan. Dengan dasar teologis terhadap Pancasila dan UUD 45 melalui semangatnya yang sangat qur'ani, jelaslah bahwa tidak tepat jika kedua dasar sistem kenegaraan kita ini dianggap sebagai tidak Islami. Meskipun secara nama, Pancasila dan UUD 45 tidak ada dalam al-Quran dan as-Sunnah, namun seperti yang ditegaskan imam al-Ghazali ${ }^{23}$, yang islami itu bukan sekedar yang ma nataqa an-nash 'apa yang ada dalam al-Quran dan Sunnah' tapi lebih dari itu, yakni, yang ma wafaqa assyar'a 'yang sesuai dengan semangat syariat'. Pandangan ini cukup untuk membantah 
keyakinan bahwa semua hukum buatan manusia itu produk kekufuran. Selagi hukum tersebut bersesuaian dengan syariat, tidak menghalalkan yang haram dan tidak mengharamkan yang halal, maka jelas Pancasila dan UUD 45 sangatlah islami.

\section{Penutup dan Kesimpulan :}

Secara umum bahwa Pancasila mengandung nilai-nilai ke-Tuhanan, kemanusiaan, persatuan, kerakyatan, dan keadilan, yaitu sebuah nilai-nilai universal yang luhur. Semangat dari nilai-nilai Pancasila tersebut sangat sesuai dengan nilainilai Islam. Bahkan apa yang diusung oleh Pancasila secara keseluruhan menjadi visi Islam dalam risalahnya. Hanya saja keduanya secara eksistensial memiliki hak otonomi tersendiri. Artinya bahwa Islam adalah agama dan Pancasila adalah ideologi. Pancasila tidak akan menjadi agama dan agama tidak akan menjadi ideologi. Tetapi secara substansial, Islam dan Pancasila merupakan satu kesatuan yang utuh dalam artian nilai-nilai yang dikandungnya. Hal ini sekaligus memberikan pemahaman bahwa perumusan ide Pancasila sejatinya diilhami oleh konsep dan nilai-nilai keislaman. Penegasan ini berdasarkan pemikiran bahwa yang dimaksud adalah nilainilai Pancasila bersesuaian dengan Islam tanpa harus menjadikan Indonesia sebagai negara Islam secara formal. Pemikiran ini pula sangat menganjurkan bahwa nilai-nilai Islam dapat tumbuh dan berkembang pada sebuah negara yang tidak menegaskan sebagai negara yang berafiliasi pada Islam.

Pancasila mengandung nilai-nilai Ketuhanan (religiusitas) sebagai sumber etika dan spiritualitas (yang bersifat vertikal-transendental) dianggap penting sebagai fundamen etik kehidupan bernegara. Maka Indonesia bukanlah negara sekuler ekstrim, yang memisahkan "agama" dan "negara" dan berpotensi untuk menyudutkan peran agama ke ruang privat/komunitas. Tetapi juga, Indonesia bukanlah :negara agama", yang hanya merepresentasikan salah satu (unsur) agama. Maka negara bersifat netral dan mengambil jarak yang sama terhadap semua agama/keyakinan, melindungi semua agama/ keyakinan, dan mengembangkan politiknya berdasarkan nilai-nilai agama. Bahkan menurut Pancasila, agama harus dapat memainkan peran publik yang berkaitan dengan etika social ${ }^{24}$. Umat Islam sebagai mayoritas penduduk Indonesia, tidak perlu ragu bahwa Pancasila merupakan bagian dari sistem ideologi yang memiliki dasar-dasar teologis dan filosofis Islam.

Kesalehan orang beriman sebagai hamba terhadap Allah ('abd Allah) bermuara dan berdampak langsung pada kesalehan dalam relasi-relasi sosialhorizontal. Kedua aspek ini menjadi ciri keseimbangan ajaran Islam. Oleh karena itu, yang seharusnya menjadi pikiran kita bersama adalah nilai-nilai Pancasila secara substansial tidak bertentangan bahkan bersesuaian dengan Islam.

Mengenai Nilai-nilai Pancasila dalam Pandangan Islam, Dr. H. Ridhahani Fidzi, M.Pd berpandangan bahwa Sila pertama dan kedua merupakan Metapisikal Fundation, Sila ketiga dan keempat merupakan Instrumental Fundation, dan Sila kelima merupakan keadilan. Karena itu kita harus melakukan: mahasabah (evaluasi), murakabah (mengawal/mengawasi), dan muhawalah (menyiasati). Seperti hal nya ungkapan yudi latif, Ridhahani Firdzi juga mengatakan bahwa kita bukan negara agama dan bukan pula negara sekuler, tapi kita negara pancasila dimana butir-butir dari panca itu sangat bersesuaian dengan nilai-nilai agama. Negara memberi ruang kepada warganya untuk melaksanakan ajaran agamanya masingmasing ${ }^{25}$. 
Kemudian Dr. Jalaluddin, mengupas mengenai Transformasi Nilai Ketuhanan dalam Kehidupan Bernegara. mengemukakan bahwa: Pancasila sebagai dasar negara mengandung makna bahwa nilai-nilai yang terkandung dalam Pancasila menjadi dasar atau pedoman bagi penyelenggaraan bernegara. Pancasila sebagai dasar negara berarti nilai-nilai Pancasila menjadi pedoman normatif bagi penyelenggaraan bernegara. Transformasi tersebut kemudian melahirkan : adanya Kementerian Agama, Pengadilan Agama, Bank Muamalat, serta lahirnya peraturan perundang-undangan tentang ekonomi syariah, Eksistensi dan Peranan MUI ${ }^{26}$

Dr. Wahyuddin, M.Si juga mengemukakan bahwa: Term Dar Al-Salam di dalam Al-Qur'an sesungguhnya digunakan sebagai gambaran tentang kehidupan di surga, yaitu kehidupan penuh bahagia di sisi Tuhan (QS. $6: 125-127,10: 25,56: 25-$ 26). Dan Dar Al-Salam bermakna "Negeri Damai" Dalam makna seperti itu, Dar AlSalam sama artinya dengan Al-Balad Al-Amin yang merupakan nama lain untuk kota Makkah. Juga sama artinya dengan Yerusyalim (Yerusalem) yang merupakan nama asli dari bahasa Suryani atau Arami untuk kota Al-Quds atau Al-Bait Al-Maqdis di Palestina di mana berdiri mesjid Aqsha. ${ }^{27}$

Prinsip dalam Pancasila merupakan cermin konsep monotheisme atau tauhid (unitas). Prinsip ini pula merupakan dasar kerohanian dan dasar moral bagi bangsa Indonesia dalam bernegara, bermasyarakat, artinya dalam aktivitas kehidupan berbangsa dan bernegara wajib mengimplementasikan dan memperhatikan petunjukpetunjuk Tuhan Yang Maha Esa.

Islam sebagai agama yang menjunjung tinggi egalitarianisme, yaitu konsep yang terbuka atas solidaritas dan ketergantungan sosial (ta`awun). Islam mengakui hak semua manusia untuk hidup layak dalam hal kesehatan, pakaian, makanan, perumahan serta usaha-usaha sosial yang diperlukan tanpa melihat perbedaan latar belakang. Islam juga menekankan hak setiap orang atas jaminan sosial di waktu mengalami pengangguran, sakit, cacat, janda/duda, lanjut usia atau mengalami kekurangan. Standar hidup semacam ini hanya mungkin dalam sebuah tatanan sosial yang sehat, di mana individu dengan individu, individu dengan kelompok, dan kelompok dengan kelompok saling memelihara hubungan sosial kuat. Hal ini menjadi spirit Islam dalam bertanggung jawab dan saling berkorban agar tercipta masyarakat yang saling berbagi, tolong menolong dan gotong-royong (QS. al-Maidah 5: 2).

Persatuan Indonesia pada prinsipnya menegaskan bahwa bangsa Indonesia merupakan Negara Kebangsaan. Bangsa yang memiliki kehendak untuk bersatu, memiliki persatuan perangai karena persatuan nasib. Persatuan berarti menyiratkan arti adanya keragaman, bukan berarti memaksakan persamaan, yaitu bhineka tunggal ika. Persatuan dalam hal ini adalah persatuan kebangsaan Indonesia yang dibentuk atas bersatunya beragam latar belakang sosial, budaya, politik, agama, suku bangsa, dan ideologi yang berada di wilayah Indonesia. Dalam hal ini Islam sejalan dengan konsep Pancasila karena secara konkret Islam mengajarkan tentang upaya-upaya menyikapi keanekaragaman masyarakat dan bangsa. Yaitu persatuan dan kesatuan manusia perlu diikat oleh persaudaraan. Persaudaraan yang dimaksud ialah "persaudaraan universal" di mana umat manusia diikat tanpa mengenal warna, identitas etnis dan agama yang dipeluk. Nilai-nilai tentang persaudaraan ini sangat jelas disuratkan dalam Al-Qur'an. "dan umat manusia adalah umat yang satu" (QS. al-Baqarah [2]: 213) dan "semua Muslim adalah bersaudara” (QS. Yunus [10]: 4).

Endnote : 
${ }^{1}$ Husnul Khotimah, S. S.Ag, M.Si., adalah alumni peserta LEMHANAS RI, mahasiswa S3 University Malaya Kuala Lumpur, Malaysia.

2 Dr. Erni Budiwanti, Islam Sasak, hlm. 70.

${ }^{3}$ Toto Tasmara, Menuju Muslim Kaffah; Menggali Potensi Diri, Jakarta: Gema Insani, 2000, hlm. 226

${ }^{4}$ Prof. Dr. Abu Su'ud, Islamologi; Sejarah, Ajaran dan Peranannya dalam Peradaban Umat Manusia, Jakarta: PT Rineka Cipta, 2003, hlm. 141.

${ }^{5}$ Khalili khalil, Empat Tingkat Tauhid Menurut Imam Ghazali

${ }^{6}$ Salim Taib, Islam dan Kefitrahan pancasila, Harian Halmahera, 2019

${ }^{7}$ Abu 'Abdillah Muhammad ibn Isma'il al-Bukhari, Sahih al-Bukhari, (Cet. III; Beirut: Dar Ibn Katsir, 1407 H./1987 M.), Juz. II, h. 848. Abu al-Husain Muslim ibn al-Hajjaj al-Naisaburi, Sahih Muslim, (Beirut: Dar Ihya" al-Turas al- 'Arabi, t.th.), Juz. III h. 1459

${ }^{8}$ Let,Jen Ir H, Azwar Anas, Korelasi Pancasila, UUD45 dengan Islam, 2014

${ }^{9}$ Enung Asmaya, Hakekat Manusia Dalam Tasawuf Al-Ghazali, KOMUNIKA: Jurnal Dakwah dan Komunikasi Vol. 12, No. 1, Januari - Juni 2018, 123-135

${ }^{10}$ MK Ridwan, Penafsiran Pancasila dalam Perspektif Islam; Peta dan Konsep, Dialogia, Vol. 15, No. 2, Desember 2017

${ }^{11}$ MK Ridwan, Penafsiran Pancasila dalam Perspektif Islam; Peta dan Konsep, Dialogia, Vol. 15, No. 2, Desember 2017

12 Yudi latif “ Negara Paripurna” Jakarta, Gramedia, 2011

${ }^{13}$ Toto Tasmara, Menuju Muslim Kaffah, hlm. 383.

${ }^{14}$ Dr. Erni Budiwanti, Islam Sasak, hlm. 72.

${ }^{15}$ Dr. M. Dhiaudiddin Rais, Teori Politik Islam, Jakarta: Gema In i, 2001, hlm. 194.

${ }^{16}$ Yudi latif “ Negara Paripurna” Jakarta, Gramedia, 2011

17 Prof. Dr. Buya Syakur, MA “Refleksi Kemerdekaan Republik Indonesia Ke-74” , 2019

${ }^{18}$ Mirwan Fikri Muhkam, Muh. Khaedir, Pancasila Sebagai Spirit Pluralisme Keberagaman Bangsa Penguatan Integrasi Nasional Di Era Disrupsi Dalam Perspektif Pancasila, Prosiding Seminar Nasional Jurusan Politik Dan Kewarganegaraan, 111-118

${ }^{19}$ Let,Jen Ir H, Azwar Anas, Korelasi Pancasila, UUD45 dengan Islam, 2014

${ }^{20}$ Dr. M. Dhiaudiddin Rais, Teori Politik Islam, hlm. 274.

${ }^{21}$ H.A. Mukti Ali, Memahami Beberapa Aspek Ajaran Islam, Bandung: Penerbit Mizan, 1991, hlm.158159.

${ }^{22}$ Maksudnya mengumpulkan dan menghitung-hitung harta yang karenanya dia menjadi kikir dan tidak mau menafkahkannya di jalan Allah.

${ }^{23}$ Pemikiran Ahmad Syafii Maarif, Negara dan Syariat Islam, Millah, Vol 9, No.2, 2011.

${ }^{24}$ Yudi latif “ Negara Paripurna” Jakarta, Gramedia, 2011

${ }^{25}$ Dr. H. Ridhahani Firdzi, M. Pd. Nilai-nilai Pancasila dalam Pandangan Islam, Pengajian Ramadhan $1437 \mathrm{H}$

${ }^{26}$ Dr Jalaludin, Transformasi Nilai Ketuhanan dalam Keidupan Bernegara, Pengajian Ramadhan $1437 \mathrm{H}$

${ }^{27}$ Dr. Wahyudin, M.Si “Negara Pancasila sebagai Perwujudan Daru Salam” Pengajian Ramadhan 1437 $\mathrm{H}$ 